\title{
Moisture distribution within a maize crop due to dew
}

\author{
A. J. ATZEMA, A. F. G. JACOBS \& L. WARTENA
}

Department of Meteorology, Wageningen Agricultural University, Duivendaal 2, NL 6701 AP Wageningen, Netherlands

Received 25 July 1989; accepted 5 March 1990

\begin{abstract}
During 16 nights in September and October 1986, the process of dew formation was studied within a maize crop. With the Bowen ratio energy balance technique the total dewfall from above the canopy was measured. By estimating the soil characteristics and measuring the soil moisture and temperature gradients of the top soil, an assessment of the dewrise from the soil could be made. To estimate the distribution of free water within the crop, the liquid water profile was measured with Leick plates at 5 levels. Dewfall proved to contribute most to the total dew deposition. As an average for the experimental period, nearly $5 \%$ could be attributed to dewrise and $95 \%$ could be attributed to dewfall. On the 10 occasions, the total amount of dew ranged between 0.01 and $0.41 \mathrm{~mm}$ per night. To obtain a simple but rough indication for the amount of dew, the difference between the minimum and midday dew point temperature could be applied, or, if the soil was well-watered, the top soil temperature gradient could be applied.
\end{abstract}

Keywords: dew, Leick plates, maize, dewrise, dewfall, dew profile, Bowen ration, soil diffusivity

\section{Introduction}

In agriculture, dew plays an important role in a positive as well as in a negative sense (Wallin, 1967). Examples are easily given. When dew is formed during the night, the stomata are commonly open as a result. This means that, after sunrise, the plants assimilate without restriction due to the very low stomatal resistance to $\mathrm{CO}_{2}$. The result is that the plant grows better (Slatyer, 1967).

Though dew mostly consists of a small amount of free liquid water, it can play an important role in the recovery of the water content of a plant after extreme water loss (Went, 1955). In this case absorption of dew by the leaves contributes to the recovery of the turgor. This dew benefit seems greatest in the semi-arid, arid and desert areas of the world (Baier, 1966; Slatyer, 1967; Sharma, 1976).

A negative effect of dew is the development of many foliar bacterial and fungal plant pathogens on wet surfaces. Spores of fungi need a limited time to form the 
germ tube and to penetrate into the leaf. Dew provides on plants free water which is an excellent medium for fungae to germinate. Bacteria need water to reproduce. So a wet leaf is comfortable for the development of bacteria. Nights with much dew promote diseases as potato blight (Phytophthora infestans), Botrytis spp. on strawberry, blackberry, dahlia, etc. (see also Wallin, 1963; Shoemaker et al., 1977).

Dew not only affects the plants, but assesses the farmer's working schedule as well. For example, the application of pesticides and its result are highly dependent on the presence ofrdew in both favourable an unfavourable sense (Royle et al. 1986). In pressing straw, dew is unfavourable, but in pressing rough straw such as rape seed, caraway and peas, dew can play a favourable role. These crops are combined one or two weeks after cutting. Pressing straw after a spell of unsettled weather will only be efficient in the morning. The straw becomes fragile and pressing will only be efficient after dew has been formed on the plant material. That is why that pressing straw after dew formation is common practice in Western Europe.

This study was aimed to achieve a better insight into the formation of dew within a moderate tall crop canopy. The objective was to obtain an estimate of the total amount of dew formation during nocturnal periods and to get insight into the distribution of dew within a plant canopy.

\section{Theory}

The main processes playing an important role in the dew formation are:

- the radiation exchange between the earth's surface and the atmosphere,

- turbulent heat and water vapour transport within and above the plant canopy,

- the heat and the vapour transport in the underlying soil.

The origin of the condensated water vapour can be the soil as well as the atmosphere. The first process is called the dewrise and the latter dewfall. Generally, the free liquid water on leaves and other exposed surfaces of the plant canopy can originate from three seperate sources.

First, leaves and stems of plants cool many nights below the dewpoint temperature of the air in the lowest couple of meters above the plant canopy. The result will be that water vapour of the atmosphere condenses at the surface of plant elements. This is the so-called dewfall and the only dew condensation strictly considered as a net gain for the water balance (Garratt et al., 1988).

Second, during the night a soil water vapour flux can move upwardly from the soil into the atmosphere, mainly due to a strong temperature gradient in the top layer of the underlying soil. This water vapour flux can be intercepted by plant elements. This is the so-called distillation process which causes dewrise (Garratt et al., 1988).

Third, from certain parts of leaves, guttation or exudation can occur. Guttation is essentially an internal plant process not related to dew deposition. That is why this process will not be considered in the present study, but conditions for guttation to occur are often favourable to dew condensation (Long, 1955; Slatyer, 1967). An extensive description of dew formation can be found in e.g. Monteith (1957) and Wallin (1967). However, no quantitative information about the vertical free water 
distribution due to dew has been found in literature by the authors.

The amount of dewfall can be estimated by measuring the above-crop vapour flux towards the canopy. A correct technique to attain this is by using the so-called Energy Balance Bowen Ratio technique (Rosenberg et al., 1983). For a control volume from the top of th canopy until the top of the underlying soil, in which we assume that advection and photosynthisis may be neglected, we can write (Rosenberg et al., 1983):

$$
R_{\mathrm{n}}+G+H+L E+S=0 \quad\left(\mathrm{~W} \mathrm{~m}^{-2}\right)
$$

where:

$R_{\mathrm{n}}=$ net radiation

$G=$ soil heat flux

$H=$ sensible heat

$E=$ evapotranspiration or condensation

$L=$ latent heat for evaporation

$S=$ storage term of the control volume

In this budget, the fluxes at the top and bottom of the control volume are positive if they are directed towards the control volume and negative in the opposite direction. If the Bowen ratio, $\beta=H / L E$, is known, the evapotranspiration, or during the nocturnal period the dewfall, becomes:

$$
E=\frac{-\left(R_{\mathrm{n}}+G+S\right)}{L(1+\beta)} \quad\left(\mathrm{kg} \mathrm{m}^{-2} \mathrm{~s}^{-1}\right)
$$

Assuming equality of the eddy transfer coefficients for heat and water vapour, $K_{\mathrm{H}}$ and $K_{\mathrm{v}}$, respectively, the Bowen ratio, $\beta$, may be written:

$$
\beta=\gamma \frac{\Delta T}{\Delta e}
$$

where:

$\Delta T=T_{2}-T_{1}(\mathrm{~K})$

$\Delta e=e_{2}-e_{1}(\mathrm{~Pa})$

$\gamma=c_{\mathrm{p}} p / L \epsilon(=67 \mathrm{~Pa} \mathrm{~K}-1)$

in which:

$p=$ atmospheric pressure

$c_{\mathrm{p}}=$ specific heat capacity

$\epsilon^{\mathrm{p}}=$ ratio between the molar masses of vapour and dry air

The vapour pressure $e$ can be calculated by the dry and wet bulb temperature.

The amount of dewrise from the underlying soil compartment can be estimated by measuring the moisture flux at the interface soil-air, or, by measuring the moisture flux as close as possible near the interface in one of the compartments. 
Here, we choose to measure this flux on the soil system since measurements near the soil in the air system are seriously distributed by the complex within-canopy flow. The general equation describing the moisture flow, $q$, in the soil may be written (Philip \& de Vries, 1957):

$$
\frac{q}{\varrho}=D_{\Theta} \frac{\mathrm{d} \Theta}{\mathrm{d} z}-D_{\mathrm{T}} \frac{\mathrm{d} T}{\mathrm{~d} z}-K\left(\mathrm{~m} \mathrm{~s}^{-1}\right)
$$

where:

$q=$ liquid water density flux $\left(\mathrm{kg} \mathrm{m}^{-2} \mathrm{~s}^{-1}\right)$

$\varrho=$ density of the liquid water $\left(\mathrm{kg} \mathrm{m}^{-3}\right)$

$D_{\Theta}=$ isothermal total diffusivity $\left(\mathrm{m}^{2} \mathrm{~s}^{-1}\right)$

$D_{T}=$ thermal total diffusivity $\left(\mathrm{m}^{2} \mathrm{~s}^{-1} \mathrm{~K}^{-1}\right)$

$K=$ (unsaturated) hydraulic conductivity $\left(\mathrm{m} \mathrm{s}^{-1}\right)$

$\theta=$ volumetric moisture content $(-)$

$T=$ temperature $(\mathrm{K})$

$Z$ = height $(\mathrm{m})$

\section{Materials and methods}

As part of an extensive measurement programme, the formation of dew within a mature maize crop (Zea mays L., cv. Vivia) was measured during 16 nights in September and October 1986. During this period, the crop had a height $(h)$ of $2.20 \mathrm{~m}$ and the leaf area index (LAI; one-sided total leaf area, green as well as senescent leaves, per unit ground surface) decreased from 3.2 (23 September) to 0.3 (17 October). The experimental site was located in the centre of the Netherlands $\left(51^{\circ} 59^{\prime} \mathrm{N}\right.$, $5^{\circ} 45^{\prime} \mathrm{E}$ ). The site was about $150 \mathrm{~m}$ by $200 \mathrm{~m}$ large and was surrounded by other agricultural fields on which mainly maize was planted.

Dry and wet bulb temperature measurements were made above the crop with aspirated psychrometers at heights of $2.5 \mathrm{~m}$ and $3.5 \mathrm{~m}$. At the same levels, the mean windspeed was measured with sensitive cup anemometers with a starting speed of $0.20 \mathrm{~m} \mathrm{~s}^{-1}$. These measurements were used to estimate the Bowen ratio. The net radiation was estimated with a Funk net radiometer at a height of $6.0 \mathrm{~m}$.

At depths of $0.01,0.03,0.05,0.1,0.2,0.5,1.0$ and $1.5 \mathrm{~m}$, soil temperature measurements were made with Pt-100 elements and at a depth of $20 \mathrm{~mm}$ the soil heat flux was measured with a flux plate (TNO transducer WS 31-Cp). To obtain correct values for the soil heat flux at the ground surface, corrections were made for the heat capacity of the soil (Fritschen \& Gay, 1979; Fuchs \& Tanner, 1968) and for the flux plate dimensions and the ratio fo the transducer conductivity to that of the medium, according to Philip (1961).

The heat storage change of the canopy $(S)$ was estimated by multiplying the mean heat capacity of plant canopy per unit area of underlying soil by the change of mean canopy temperature. For the mean canopy temperature, the averaged value of the air temperature just above the canopy and the temperature of the top soil was taken.

The top soil moisture profile was measured at depths of $20,30,40,50,70$ and $100 \mathrm{~mm}$ by a dielectric soil water content meter. Details about this measurement 
technique as well as the applied measurement procedure can be found elsewhere (Halbersma et al., 1987)

At the experimental site, the soil profile consisted of sand with a humic top layer. This top horizon consisted of gravel and coarse sand and had a thickness of approximately $200 \mathrm{~mm}$. Between 200 and $400 \mathrm{~mm}$ there was a podzolic horizon with less humus and iron bonds than in the top level. From both layers the hydraulic conductivity and diffusivities were estimated (Kabat et al., in press). The signals were carried to a van about $100 \mathrm{~m}$ from the instruments. Here, the signals were sampled every minute and on-line reduced to $900 \mathrm{~s}$ averages. The mean quantities were stored on cassette tape for futher analysis. More details about the experimental site and the instrumentation used can be found elsewhere (Jacobs \& van Boxel, 1988).

To obtain an estimate of the distribution of free liquid water within the crop canopy, Leick plates were horizontally installed at heights of $0.4,0.8,1.2,1.6$ and 2.0 m (one Leick plate per level). The Leick plates (Staatlichen Porzellan Manufaktur, Berlin) were composed of silicaceous earth and gypsum and were moulded into circular discs of $5 \mathrm{~mm}$ thickness and $113 \mathrm{~mm}$ in diameter (one-sided area $100 \mathrm{~cm}$ ). Each night at sunset, the plates were installed in the field. At sunrise the total mass of each plate was estimated by weighing. After drying the plates in a furnace $\left(60^{\circ} \mathrm{C}\right.$ during 6 hours), the dry mass of the plates was estimated and the difference of mass between the dry and wet plates was assumed to be the amount of dew deposit on the plates.

\section{Results and discussion}

During the selected period, the crop was senescing and the total leaf area index (green and dead leaves), LAI, decreased rapidly. The course of the LAI during this period has been depicted in Figure 1.

To get an idea of the mean leaf area distribution, A, (i.e., the one-sided leaf surface per volume) of the crop during the selected period, the relative leaf area density, $\mathrm{Ah} / \mathrm{LAI}$ as function of the relative height, $z / h$, has been depicted in Figure 2 . The area under the curve is equal to 1 . From this result it can be inferred that the leaf area distribution had a maximum more or less just above the middle of the crop height.

All measured and estimated dew data and the mean weather data from sunset until sunrise during the 16 nights are given in Table 1. Besides, in this table the type of liquid water distribution and the total leaf area index, LAI, has been given.

From the obtained results, three types of moisture distribution within the canopy can be observed. Representative examples of these types have been plotted in Figure 3. In this figure, the distribution of the amount of liquid water per unit plate surface (one-sided) has been depicted as a function of height. The dew deposits are expressed in mm per night.

Type a (13 October): the thickness of the water layer on the plates increased proportional to the height within the crop from about $0.8 \mathrm{~m}$ to the top of the canopy. So the thickest water layer was formed in the top of the canopy $(h=2.2 \mathrm{~m})$.

Type $b$ ( 30 September): there was a strong increase of the amount of liquid water 


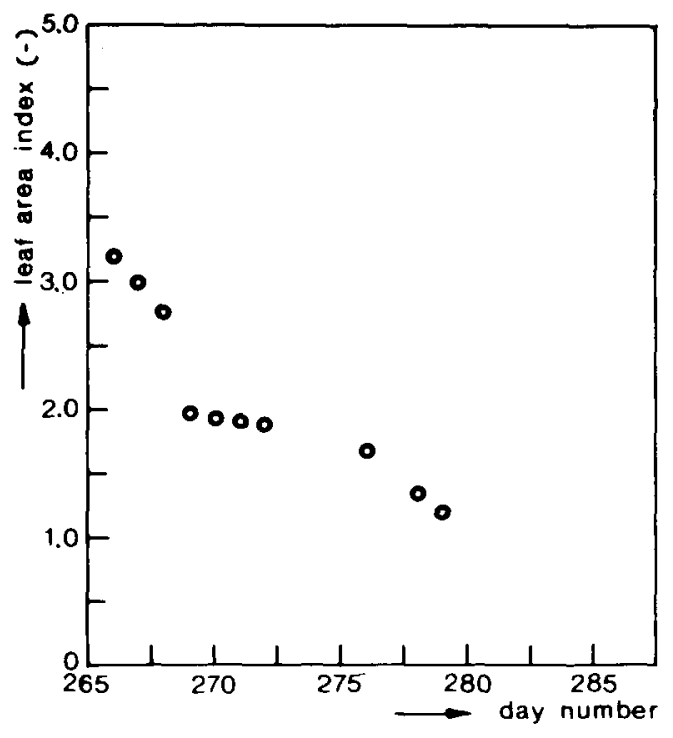

Fig. 1. The course of the leaf area index, LAI, during the rapid senescing period (23 September until 9 October).

Table 1. Measured and calculated data, mean meteorological values from sunset until sunrise and some important parameters. $T_{\mathrm{d}}-T_{\min }=$ dew point temperature (at $12 \mathrm{GMT}$ ) minimum temperature during the night at $0.40 \mathrm{~m}$ above the top of the canopy; $\Delta T_{\mathrm{s}} / \Delta z=$ mean gradient of the soil temperature during the night between 10 and $30 \mathrm{~mm}$. The net radiation is added up from sunset until sunrise.

\begin{tabular}{|c|c|c|c|c|c|c|c|c|c|c|}
\hline \multirow{2}{*}{$\begin{array}{l}\text { Date } \\
\text { in } \\
1986\end{array}$} & \multirow[t]{2}{*}{ Type } & \multirow[t]{2}{*}{ LAI } & \multirow{2}{*}{$\begin{array}{l}\text { Total } \\
\text { dew } \\
\text { Leick } \\
(\mathrm{mm})\end{array}$} & \multirow{2}{*}{$\begin{array}{l}\text { Total } \\
\text { dew } \\
\text { calc. } \\
\text { (mm) }\end{array}$} & \multirow{2}{*}{$\begin{array}{l}\text { Dew- } \\
\text { fall } \\
\text { calc. } \\
(\mathrm{mm})\end{array}$} & \multirow{2}{*}{$\begin{array}{l}\text { Dew- } \\
\text { rise } \\
\text { calc. } \\
(\mathrm{mm})\end{array}$} & \multirow{2}{*}{$\frac{\begin{array}{l}\text { Wind- } \\
\text { speed }\end{array}}{\left(\mathrm{m} \mathrm{s}^{-1}\right)}$} & \multirow{2}{*}{$\begin{array}{l}\begin{array}{l}\text { Net } \\
\text { rad. }\end{array} \\
\left(\mathrm{kJ} \mathrm{m}^{-2}\right)\end{array}$} & \multirow{2}{*}{$\begin{array}{l}T_{\mathrm{d}}-T_{\min } \\
\left.{ }^{\circ} \mathrm{C}\right)\end{array}$} & \multirow{2}{*}{$\frac{\Delta T_{\mathrm{s}} / \Delta z}{\left({ }^{\circ} \mathrm{C}\right)}$} \\
\hline & & & & & & & & & & \\
\hline $.09-23$ & $b$ & 3.20 & 0.37 & 0.34 & 0.322 & 0.015 & 0.05 & -751 & -0.9 & -0.87 \\
\hline $09-24$ & b & 2.99 & 0.23 & 0.40 & 0.390 & 0.010 & 1.09 & -1821 & -6.6 & -3.30 \\
\hline $09-25$ & a & 2.75 & 0.30 & 0.40 & 0.373 & 0.027 & 0.51 & -1549 & -5.4 & -3.83 \\
\hline $09-29$ & $\mathrm{c}$ & 1.97 & 0.06 & 0.01 & 0.010 & 0.003 & 0.61 & -194 & +0.9 & 1.14 \\
\hline $09-30$ & $b$ & 1.94 & 0.33 & 0.41 & 0.386 & 0.023 & 0.41 & -757 & -7.4 & -2.65 \\
\hline $10-01$ & b & 1.91 & 0.30 & 0.32 & 0.309 & 0.012 & 0.34 & -637 & -3.6 & -2.43 \\
\hline $10-02$ & $b$ & 1.89 & 0.24 & 0.25 & 0.233 & 0.013 & 0.34 & -547 & -4.9 & -1.43 \\
\hline $10-06$ & $\mathbf{a}$ & 1.68 & 0.20 & 0.23 & 0.222 & 0.012 & 0.67 & -865 & -3.0 & -1.01 \\
\hline $10-08$ & $a$ & 1.35 & 0.13 & 0.24 & 0.224 & 0.016 & 0.26 & -620 & -1.2 & -1.06 \\
\hline $10-09$ & a & 1.20 & 0.20 & 0.39 & 0.376 & 0.016 & 0.72 & -1195 & -6.5 & -1.73 \\
\hline $10-12$ & $\mathrm{c}$ & 0.72 & 0.04 & 0.59 & 0.583 & 0.013 & 1.00 & -2403 & -2.3 & -1.12 \\
\hline $10-13$ & $\mathrm{a}$ & 0.58 & 0.05 & 0.33 & 0.309 & 0.022 & 0.28 & -498 & -3.6 & -2.60 \\
\hline $10-14$ & $c$ & 0.44 & 0.04 & 0.09 & 0.084 & 0.004 & 0.76 & -1436 & +2.8 & +0.10 \\
\hline $10-15$ & c & 0.39 & 0.02 & 0.12 & 0.124 & 0.001 & 0.80 & -398 & +0.5 & +0.76 \\
\hline $10-16$ & $\mathbf{a}$ & 0.34 & 0.03 & 0.42 & 0.396 & 0.022 & 1.20 & -1277 & -4.7 & -2.41 \\
\hline $10-17$ & $c$ & 0.29 & 0.02 & 0.08 & 0.060 & 0.017 & 0.81 & -1675 & -0.4 & -2.43 \\
\hline
\end{tabular}




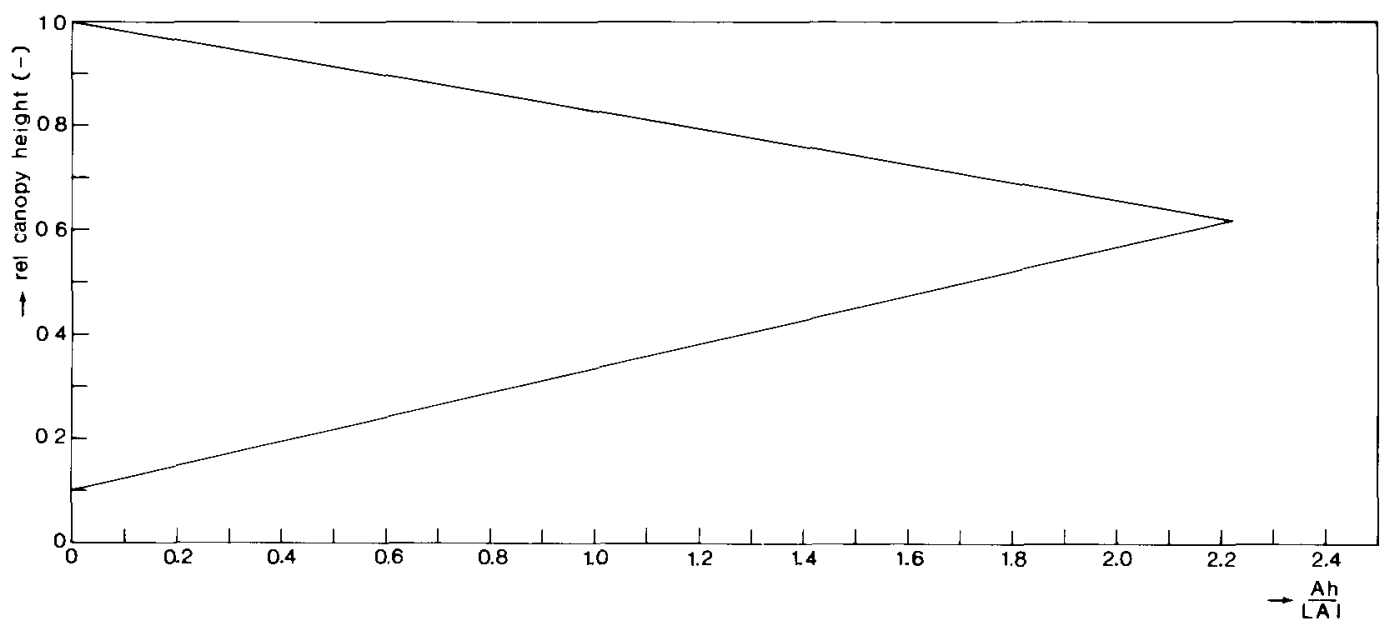

Fig. 2. The relative leaf area distribution, $\mathrm{Ah} / \mathrm{LAI}$, as function of the relative height, $z / h$, for the maize crop during September and October 1986. The area under the curve is equal to 1.

from $0.8 \mathrm{~m}$ until about $1.2 \mathrm{~m}$. Between $1.2 \mathrm{~m}$ and $1.6 \mathrm{~m}$, the thickness of the water layer was more or less constant. Beyond the latter height, the water layer increased again.

Type c (12 October): the liquid water distribution showed a maximum at a height of about $1.6 \mathrm{~m}$.

We expect that meteorological factors cause remarkable differences in the relative liquid water distribution. Nevertheless, we did not succeed in a straight forward explanation of the obtained results. Further additional research will be necessary.

A relation must exist between the total amount of liquid water and the measured amount of water on the Leick plates (Leick, 1932). It is reasonable to assume that this relation must depend on the architecture of the plant canopy. If, as a first rough estimate, it is assumed that the actual amount of free water within the canopy is linearly related to the leaf area density, an assessment of the actual free water distribution can be calculated and the result of this procedure for the three categories is depicted in Figure 4 as function of the height. For each date the leaf area distribution was known and has been used to estimate the total water distribution.

Dew occurs particularly on nights when the windspeed is low (about $2 \mathrm{~m} \mathrm{~s}^{-1}$ or less), the earth's surface cools by a net loss of long wave radiation, and when the relative humidity approaches saturation. These conditions are fulfilled nearly every night. Consequently, nearly every night some dew will be formed.

Dew can be caused by dewfall and dewrise. It is interesting to know which of both processes dominates. In Figure 5 the calculated amount of dewrise calculated according to Equation 4 has been depicted versus the amount of dewfall calculated according to Equation 2 for all data. The linear regression fitted to the data resulted in $y=0.039 x+0.004$ with a standard error of estimate of 0.005 and a linear corre- 


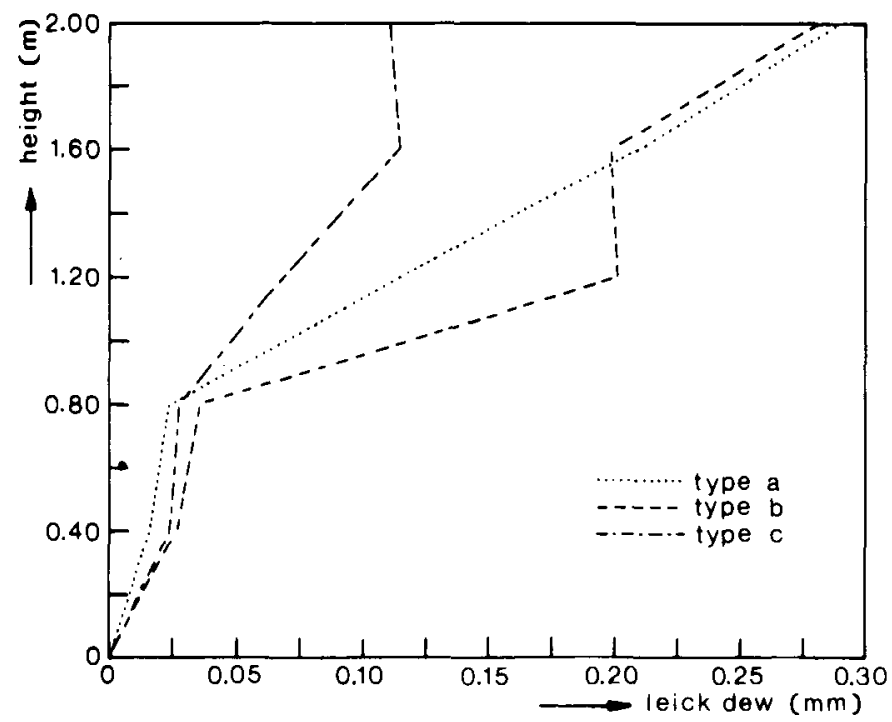

Fig. 3. A representative example of the three different types of liquid water distribution within the maize crop. The dew deposits are expressed in mm.

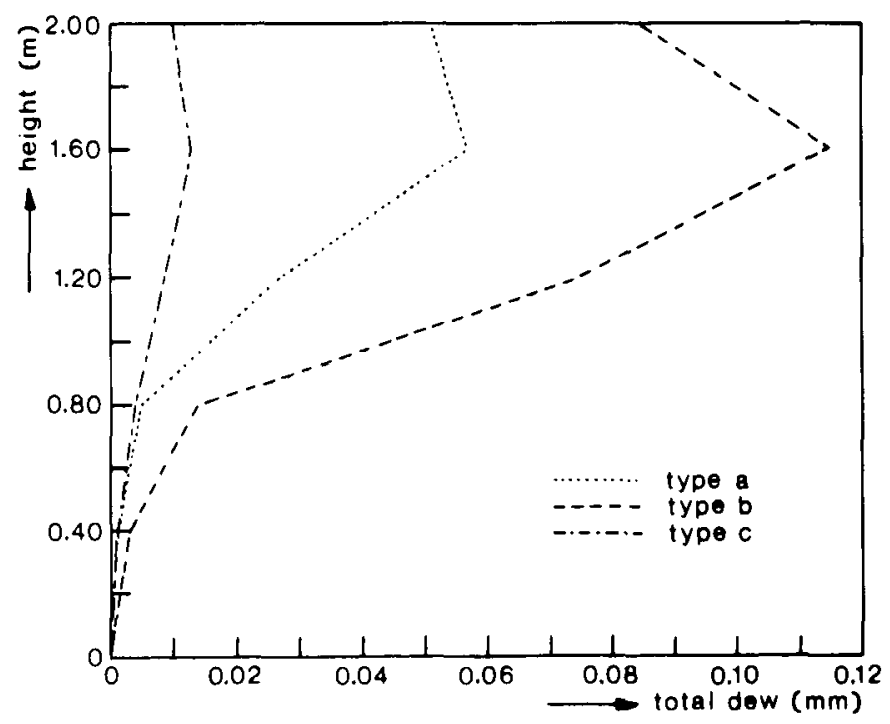

Fig 4. The calculated amount of dew deposit on the leaves by assuming that the total amount of liquid water in the canopy is linear dependent on the leaf area index (LAI). 
lation coefficient of $r=0.69$. From this result it can be concluded that, first, both processes are very weakly correlated, and, second, that the process of dewfall is the most important source of dew formation in this maize canopy.

The latter result is different from that found for a short grass cover. For example, Monteith (1957) found that the amount of dewfall and dewrise were more or less equal with a slight preference for the dewrise process. The result that within a tall canopy dewfall was more important than dewrise was also found in a wheat canopy. Burrage (1972), for example, found that, on an average, dewfall was twice as important as dewrise.

It is interesting to note that for a tall crop it is not obvious that the dewfall process will be dominant. During the night the above-crop atmosphere will stabilize whereas within the crop canopy, due to cooling by radiation at the top of the canopy and to the soil heat flux at the bottom of the canopy, the air will be unstable. This effect will reduce the dewfall process but will increase the dewrise process for a wellwatered soil. On the other hand, a tall and not too sparse vegetation reduces the amplitude of the daily temperature wave in the soil. The moisture flux in the soil (Equation 4) contains three components. However, as Monteith (1957), Philip \& de Vries, (1957) and Garrat \& Segal (1988) suggest, for a non-saturated soil, the thermal term may be of potential importance only. This was confirmed by the present results. Since the temperature gradient is mostly the only important soil potential which causes moisture transport in the top soil, a tall and not too sparse vegetation reduces the dewrise. The results of Figure 5 suggest that the latter effect is more important in the present results, consequently here the dewfall process is dominant.

In Figure 6, the calculated total amount of dew has been plotted versus the total amount of measured dew deposit on the Leick plates. Here, the calculated total amount of dew is the sum of dewfall and dewrise and has been calculated by applying Equations 2 and 4, respectively. For sparse vegetation the major part of the dew will deposit on the soil surface. That is why in Figure 6 only the results have been depicted for LAI $>1$. The unbiased linear regression line is $y=0.99 x+0.065$ with a standard error of estimate of 0.06 and a linear correlation coefficient of $r=0.77$.

It is of practical interest to find a simple parameter (or a limited number of parameters) that gives an indication of the total amount of dew deposit during the night. From Table 1 it can be inferred that the difference between minimum temperature during the night and the dewpoint temperature at daytime, (taken 12 GMT) can be considered as such a simple practical parameter. In Figure 7 the calculated total amount of dew has been plotted versus this parameter. The linear regression fitted to the data resulted in $y=-0.036 x+0.16$ with a correlation coefficient of $r=-0.80$ and a standard error of estimate of 0.07 .

The measurement period was preceded by a wet spell, where the topsoil had reached more or less field capacity. Under this condition, the mean temperature gradient (between 0.01 and $0.03 \mathrm{~m}$ depth) of the top soil proved to be also a simple and practical indication for the amount of dew deposits. In Figure 8, the calculated total amount of dew has been plotted versus this parameter. The linear regression fitted to the data resulted in $y=-0.076 x+0.17$ with a correlation coefficient of $r=-0.88$ and a standard error of estimate of 0.06 . 
A. J. ATZEMA, A. F. G. JACOBS AND L. WARTENA

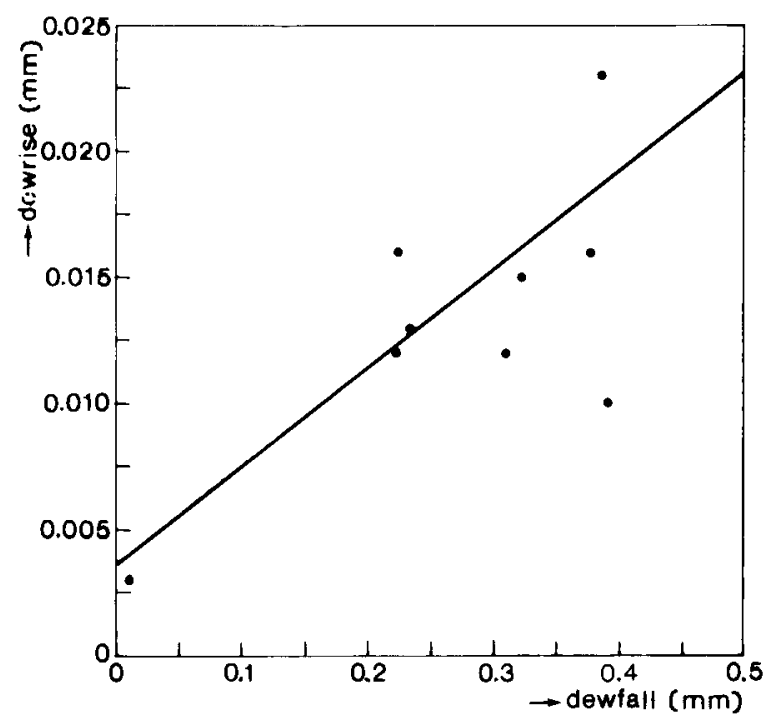

Fig. 5. The calculated amount of dewrise versus the calculated of dewfall.



Fig. 6. The calculated amount of dew versus the total amount of dew deposit on the leaves on nights when LAI $>1$. 


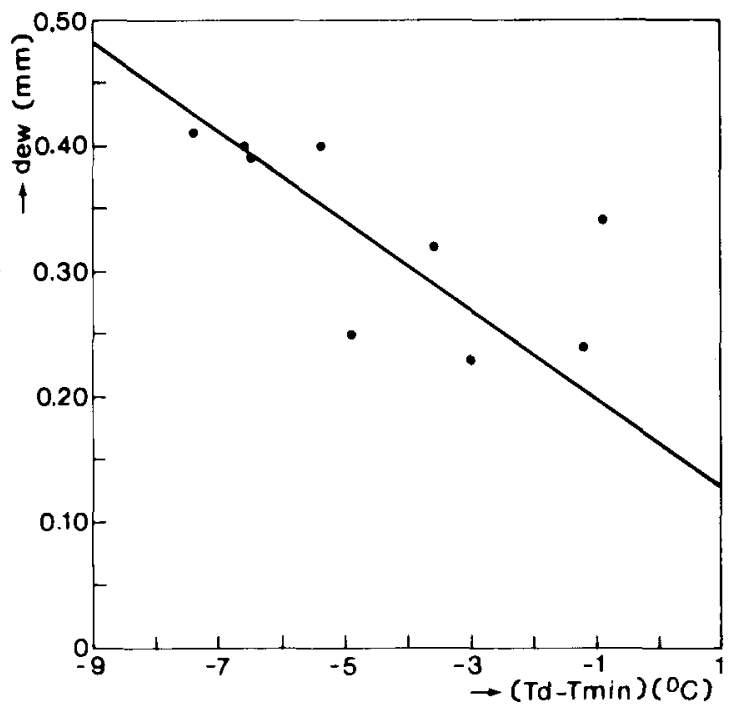

Fig. 7. The amount of calculated dew versus the temperature difference between the dew point temperature at noon (12 GMT) and the minimum temperature during the night at a height of $0.75 \mathrm{~m}$ above the top of the canopy.

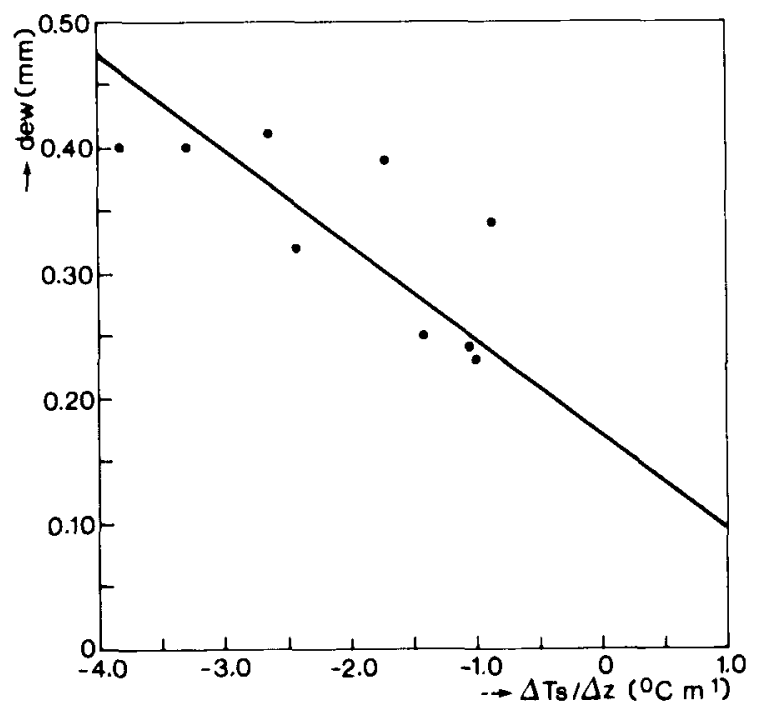

Fig. 8. The amount of calculated dew versus the mean temperature gradient of the top soil taken between 10 and $30 \mathrm{~mm}$. 


\section{Conclusions}

Dewfall is the most important source of the total dew within a mature maize canopy. Dewfall and dewrise in maize are weakly correlated. With Leick plates, a reliable moisture distribution within a not too sparse vegetation can be obtained. The difference between the minimum temperature during the night and the dewpoint temperature at noon gives an indication of the total amount of dew deposit during the night. Also the temperature gradient of the top soil is responsible for the amount of dew deposits.

\section{Acknowledgements}

The authors would like to thank the Institute for Land and Water Management (ICW) for making use of the facilities of the pilotfarm.

\section{References}

Baier, W., 1966. Studies on dew formation under semi-arid conditions. Agricultural Meteorology 3: 103-112.

Burrage, S. W., 1972. Dew on wheat. Agricultural Meteorology 10: 3-12.

Fritschen, L. J. \& L. W. Gay, 1979. Environmental Instrumentation. Springer Verlag, New York, 216 pp.

Fuchs, M. \& C. B. Tanner, 1968. Calibration and field test of soil heat flux plates. Soil Science Society of America Proceedings 32: 326-328.

Garrat, J. R. \& M. Segal, 1988. On the contribution of atmospheric moisture to dew formation. Boundary-Layer Meteorology 45: 209-236.

Halbersma, J., C. Przybyla \& A. F. G. Jacobs, 1987. Application and accuracy of a dielectric soil water content meter. Proceedings International Conference on measurement of soil and plant status, Vol. 1, p. 11-15, Utah State University, Logan, USA.

Jacobs, A. F. G. \& J. H. van Boxel, 1988. Changes of the displacement height and surface roughness length of maize during a growing season. Agriculture Forest Meteorology 42: 53-62.

Leick, E., 1932. Zur Methodik der relativen Taumessung. Beihefte zum Botanischen Centralblatt 49: $160-189$.

Long, I. F., 1955. Dew and guttation. Weather 10: 128.

Kabat, P., J. Elbers \& R. A. Feddes, (in press). Soil physical characteristics of the experimental site of pilot farm Sinderhoeve. In: Simulations of field water use and water limited production of a maize crop. Institute for Land and Water Management Research, Wageningen, $50 \mathrm{pp}$.

Monteith, J. L., 1957. Dew. Quarterly Journal Royal Meteorological Society 83: 322-341.

Philip, J. L. \& D. A. de Vries, 1957. Moisture movement in porous materials under temperature gradients. Transactions American Geophysical Union 38: 222-232.

Philip, J. L., 1961. The theory of heat flux meters. Journal of Geophysical Research 66: 571-579.

Rosenberg, N. J., B. L. Blad \& S. B. Verma, 1983. Microclimate; the biological environment. John Wiley \& Sons, New York, 495 pp.

Royle, D. J. \& D. R. Butler, 1986. Epidemiological significance of liquid water in crop canopies and its role in disease forecasting. In: Ayres P. G. \& L. Boddy (Eds), Water, fungi and plants, p. 139-156.

Sharma, M. L., 1976, Contribution of dew in the hydrological balance of a semi-arid grassland. Agricultural Meteorology 17: 321-331.

Shoemaker, P. B. \& J. W. Lorbeer, 1977. The role of dew and temperature in the epidemiology of Botrytis leaf blight of union. Phytopatology 67: 1267-1272.

Slatyer, R. O., 1967. Plant-water relationschips. Academic Press London, 366 pp. 
Wallin, J. R., 1963. Dew, its significance and measurement in phytopatology. Phytopatology 53: 1210-1216.

Wallin, J. R., 1967. Agrometeorological aspects of dew. Agricultural Meteorology 4: 85-102.

Went, F. W., 1955. Fog, mist dew and other sources of water. Yearbook Agriculture (US Department of Agriculture), p. 103-109. 